\title{
Konstruksi Hubungan Alam dan Manusia melalui Kerangka Maskulinitas Ekologis dalam Film Jungle (2017): Ekokritik Sastra
}

\author{
The Construction of Human-Nature Relationship through Ecological Masculinity \\ in Jungle (2017) Movie: Ecocriticism
}

\author{
Nuril Rinahayu $\mathbf{1}^{1, *}$ dan Bayu Kristianto ${ }^{2}$ \\ 1,2 Departemen IImu Susastra, FIB, Universitas Indonesia \\ Depok, Jawa Barat, Indonesia \\ 1,* Email: nuril.rinahayu@ui.ac.id; Orcid: https://orcid.org/0000-0002-1132-5041 \\ 2 Email: baladewabayu@gmail.com; Orcid: https://orcid.org/0000-0002-3340-8200
}

\begin{abstract}
ARTICLE HISTORY
Received 6 December 2021

Accepted 26 December 2021

Published 1 February 2022

\section{KEYWORDS}

human nature, ecology, masculinity, negotiation, wilderness.

KATA KUNCI

alam manusia, ekologis, maskulinitas, negosiasi, wilderness.

ABSTRACT

This study examines the construction of the human-nature relationship in the Jungle (2017) movie. Jungle movie presents the mindset and behavior of men through four male characters (Yossi, Marcus, Kevin, and Karl) towards the wild (wilderness) as a masculinity framework. Using a qualitative method with an ecocriticism approach, especially related to ecological masculinity by Hultman and Pulé, this study shows how the construction of human-nature relationships through masculinity framework presents ecological masculinity as a form of hegemonic masculinity negotiation. The analysis focuses on two aspects of film studies: narrative and cinematographic by Bogss and Petrie. The results of this study indicate that in the depiction of nature through the Amazon Forest, nature is positioned as something dangerous, wild, scary, and capable of killing humans. Therefore, nature is represented as an entity that dominates humans. However, men's mindset and behavior towards nature present the illusion of a human versus nature dichotomy; in this case, the Jungle movie tries to present a critique of anthropocentrism. In addition, the mindset and behavior of male characters toward nature represent male masculinity models, especially ecological masculinity, as an alternative to hegemonic masculinity.

\section{ABSTRAK}

Penelitian ini mengkaji pemahaman tentang konstruksi hubungan alam dan manusia dalam film Jungle (2017). Film Jungle menghadirkan pola pikir dan perilaku laki-laki melalui empat tokoh laki-laki (Yossi, Marcus, Kevin, dan Karl) terhadap alam liar (wilderness) sebagai kerangka maskulinitas. Penelitian ini menggunakan metode kualitatif dengan pendekatan ekokritisisme terutama terkait maskulinitas ekologis oleh Hultman \& Pulé. Penelitian ini bertujuan untuk menunjukkan bagaimana konstruksi hubungan alam dan manusia melalui kerangka maskulinitas menghadirkan maskulinitas ekologis sebagai bentuk negosiasi maskulinitas hegemonik. Selanjutnya, analisis dilakukan terhadap dua aspek studi film yakni naratif dan sinematografis dari Bogss \& Petrie. Hasil dari penelitian ini menunjukkan bahwa penggambaran alam melalui hutan Amazon, alam diposisikan sebagai sesuatu yang buruk, liar, menakutkan, dan mampu membunuh manusia sehingga alam dihadirkan sebagai entitas yang mendominasi manusia. Akan tetapi, pola pikir dan perilaku laki-laki terhadap alam justru menghadirkan ilusi dikotomi alam versus manusia, dalam hal ini film Jungle mencoba menghadirkan kritik terhadap antroposentrisme. Selain itu, pola pikir dan perilaku tokoh laki-laki terhadap alam merepresentasikan model-model maskulinitas laki-laki, salah satunya maskulinitas ekologis sebagai alternatif dari maskulinitas hegemonik.
\end{abstract}

To cite this article:

Rinahayu, N., \& Kristianto, B. (2022). Konstruksi Hubungan Alam dan Manusia melalui Kerangka Maskulinitas Ekologis dalam Film Jungle (2017): Ekokritik Sastra. Diglosia: Jurnal Kajian Bahasa, Sastra, dan Pengajarannya, 5(1), $101-118$. https://doi.org/10.30872/diglosia.v5i1.349 


\section{A. Pendahuluan}

Penggunaan alam untuk memenuhi kebutuhan manusia menjadi persoalan utama dalam kompleksitas hubungan alam dan manusia. Hal ini memberikan pemaknaan baru terhadap ekologis tidak hanya sebagai kata benda, namun kata sifat dan kata kerja untuk mendefinisikan aspek-aspek baru kehidupan manusia terhadap alam. Hultman \& Pulé (2018, p. 54) berpendapat bahwa melalui pemosisian ekologis sebagai kata kerja dalam kehidupan manusia, ekologis dapat menjadi suatu alternatif dari konstruksi yang telah tercipta dan mewakili rasionalitas dalam tindakan. Dengan demikian, hubungan alam dan manusia selalu dikonstruksikan dalam konteks sosial tertentu. Makalah ini menganalisis bagaimana hubungan alam dan manusia dikonstruksi melalui kerangka maskulinitas laki-laki dalam film Jungle (2017), terkait pola pikir dan perilaku lakilaki terhadap alam liar.

Film ini diproduksi tahun 2017 yang merupakan film drama survival biografi Australia berdasarkan kisah nyata. Film ini mengisahkan seorang petualang Israel, Yossi Ghinsberg pergi ke jantung hutan Amazon ketika bertemu dengan orang asing warga negara Austria, Karl Ruprechter yang mengajak dan mengklaim adanya eksistensi suku pribumi di dalam hutan. Kemudian, Yossi tertarik dan pergi bersama kedua temannya yang seorang guru Swiss (Marcus Stamm) dan fotografer Amerika (Kevin Gale). Dalam film, kisah berfokus pada Yossi dan Kevin, di mana Yossi hanyut terpisah dari Kevin, dan bertahan selama tiga minggu di alam liar. Di akhir film, Yossi diselamatkan oleh Kevin dengan meminta bantuan penduduk ketika akhirnya Yossi menyerah pada alam. Sementara itu, Karl dan Marcus tidak pernah terdengar kabarnya meskipun telah dilakukan pencarian.

Mengangkat persoalan konstruksi hubungan alam dan manusia, film Jungle (2017) mendeskripsikan isu tersebut lebih jelas karena persoalan tersebut tidak hanya dihadirkan melalui narasi dan dialog, tetapi juga non-naratif atau sinematografis dari film. Berbeda dengan novel dan puisi, film berkomunikasi secara langsung melalui gambar dan suara yang konkret (Boggs \& Petrie, 2017, p. 3). Dengan kata lain, kata-kata dalam narasi dan dialog serta gambar dalam film saling mendeskripsikan satu sama lain sehingga menghadirkan tema dengan jelas.

Penelitian yang menggunakan film Jungle (2017) yang disutradarai oleh Greg McLean sebagai objek analisis belum pernah dilakukan oleh akademisi sebelumnya. Bagaimanapun, beberapa ulasan menunjukkan bahwa film ini layak untuk dianalisis, terutama dalam hal persoalan lingkungan. Film Jungle (2017) menghadirkan narasi dan visual yang kuat terkait penggambaran alam liar, McLevy (2017) menyatakan bahwa film Jungle menyuguhkan beberapa adegan dengan suasana menakutkan dalam hutan yang justru memikat penonton dengan menampilkan karakteristik yang unik melalui visualnya; film ini juga memberikan gambaran visual yang benar-benar gamblang dan nyata terhadap kisah manusia bertahan hidup di tengah alam liar. Kemudian, dilansir dalam The Guardian, Luke Buckmaster (2017) menyatakan bahwa tokoh Karl dalam film menggambarkan bagaimana hutan menunjukkan kepada kita apa sebenarnya 
'kita'-merupakan lelucon yang merujuk pada kiasan bahwa entitas manusia hanya bagian kecil dibandingkan alam ketika berada di tengah alam liar. Sedangkan beberapa penelitian terdahulu terkait film yang sejenis dengan Jungle yang menggambarkan tentang pertahanan hidup di alam meliputi film Into the Wild (2007); 127 Hours (2010); dan The Revenant (2015). Penelitianpenelitian terkait film dengan pertahanan hidup di alam menunjukkan bahwa konstruksi narasi dan karakter tokoh yang dibangun turut menentukan konsumsi film dan membentuk penggambaran peran alam.

Penelitian terkait karya sejenis dengan film Jungle (2017) yakni beberapa penelitian dengan menggunakan film Into the Wild (2007) menunjukkan bahwa narasi tokoh dan deskripsi alam merepresentasikan ironi terkait alam liar itu sendiri seperti peran alam bagi manusia. Batat \& Wohlfeil (2009, pp. 372-377) berfokus pada konsumsi film Into the Wild berkaitan dengan pengalaman hidup pribadi; bahwa ketertarikan terhadap jenis film seperti Into the Wild menunjukkan adanya keterlibatan pribadi dengan narasi film, karakter, dan filosofi yang mendasar seperti empati terhadap karakter Chris dan narasi film yang faktual yang dipengaruhi oleh alam. Penelitian lain yang menganalisis film Into the Wild yakni berkaitan dengan representasi pencarian eco-heroisme. Korteweg dan Oakley (2014, pp. 131-143) menganalisis pencarian eko-heroisme dalam narasi media film dengan membandingkan film Grizzly Man (2015) dan Into the Wild (2017) dalam menggambarkan status heroik di hutan belantara Alaska. Menurut Korteweg dan Oakley, kedua film menampilkan tokoh utama yang tidak menyadari sifat dasar (basic nature) dari alam yang mereka jadikan tempat tinggal dan tanpa meninjau gagasan pribumi (pribumi merupakan representasi terkuat dari eko-heroisme) terhadap alam; namun, kehadiran tokoh Treadwell dalam Grizzly Man dan McCandless dalam Into the Wild justru menjadi panutan dan teladan bagi laki-laki kulit putih yang menimbulkan makna berbeda dari status eko-heroisme seperti bahwa kembali pada alam liar merupakan hal yang patut dijadikan contoh. Penelitian Croteau (2020, pp. 209-229) menganalisis film Into the Wild dari perspektif peran alam yaitu alam sebagai pemelihara dan alam liar. Croteau menemukan bahwa dalam film ini terdapat ironi yang jelas bahwa alam liar dianggap oleh tokoh McCandless sebagai kebebasan paling absolut. Akan tetapi, kebebasan tersebut justru membawa manusia dalam pertempuran dengan alam liar; padahal seharusnya pertempuran tersebut adalah konflik internal manusia dengan dirinya sendiri untuk mencapai kebebasan absolut tersebut.

Kemampuan bertahan hidup manusia dalam alam liar juga direpresentasikan dalam film 127 Hours (2010) dan The Revenant (2015). Penelitian-penelitian terdahulu terkait film sejenis menunjukkan bahwa dalam film yang menggambarkan kemampuan manusia bertahan hidup, konstruksi karakter dan alam sangat kental digambarkan. Contessa (2012, pp. 89-92) melalui konsep ecological identity, mengungkapkan bahwa film 127 Hours merepresentasikan konflik dalam diri manusia dan persoalan sosial yang kemudian alam sebagai refleksi atas persoalan tersebut. Selain itu, menurut Contessa, film 127 Hours merepresentasikan penggunaan alam liar sebagai sarana meditasi bagi manusia. Berbeda dengan Contessa, Tierney (2021, pp. 89-104) menganalisis 
kolonialisme dan anglosentrisme melalui kacamata poskolonial-ekokritisisme dalam film The Revenant (2015). Melalui analisis naratif dan tekstual, Tierney menemukan bahwa konstruksi karakter kulit putih bertahan hidup dalam musim dingin yang keras dan hampir mengalami kematian, dianggap sebagai ideologi yang mendukung dan mengistimewakan kemampuan satu orang kulit putih.

Untuk melihat bagaimana hubungan manusia/laki-laki dan alam dalam film, beberapa penelitian yang berkaitan dengan alam-manusia menunjukkan adanya kompleksitas hubungan tersebut. Hubungan alam dan manusia tidak hanya merepresentasikan persoalan alam, tetapi juga persoalan sosial manusia. Zonn \& Altken (1994) menganalisis film Storm Boy (1976) terkait dengan hubungan laki-laki dan burung pelikan sebagai simbol dari lanskap Australia dan gender. Kemudian, Yuan Pan (2020) meneliti hubungan alam dan manusia dalam filmfilm animasi Asia Timur. Pan menggunakan lima film dari Hayao Miyazaki; kelima film tersebut mengelaborasi tema lingkungan dengan bentuk-bentuk perlawanan atau gerakan seperti kesetaraan gender (feminisme) dan perlawanan terhadap perang atau kekerasan (pasifisme) sehingga membentuk ideologi bahwa manusia harus berjuang untuk hidup selaras dan sejajar dengan alam. Potter (2019) mengkaji film Avatar menggunakan pendekatan poskolonialekokritisisme. Dalam penelitian Potter, hubungan manusia-alam erat kaitannya dengan perkembangan teknologi dan poshumanis. Menurut Potter, film Avatar mempromosikan ideologi bio-konservatisme melalui hubungan alam, manusia, dan teknologi.

Beberapa penelitian terkait konstruksi maskulinitas yang direpresentasikan dalam film menunjukkan bahwa maskulinitas berkaitan dengan peran dari penghadiran tokoh laki-laki yang semakin bervariasi. Greven (2009, pp. 22-43) meneliti konstruksi maskulinitas kontemporer yang direpresentasikan dalam filmfilm Hollywood. Menurut Greven dalam dua dekade terakhir, film-film Hollywood menghadirkan perpecahan maskulinitas Amerika melalui penghadiran dua tokoh laki-laki protagonis, yakni maskulinitas laki-laki berdasarkan penampilan (narsistik); dan maskulinitas laki-laki berdasarkan hubungan seksual (masokistik). Di sisi lain, Loftsdóttir et al. (2017, pp. 1225-1242) memadukan analisis terhadap maskulinitas dan pariwisata di Iceland dalam serial TV berjudul Trapped. Loftsdóttir et al. menemukan bahwa penghadiran tokoh laki-laki sebagai yang terjebak menunjukkan tujuan serial TV yakni menampilkan Islandia sebagai tujuan pariwisata dan ajang promosi dari wilayah pariwisata.

Berbeda dengan penelitian-penelitian terdahulu yang telah diuraikan, tujuan penelitian ini adalah membongkar konstruksi maskulinitas laki-laki yang menghadirkan dikotomi terhadap alam (wilderness) dalam film petualangan dan bertahan hidup di hutan belantara. Penelitian-penelitian terdahulu yang membahas persoalan hubungan manusia/laki-laki dan alam yang telah diuraikan di atas dapat dikaji lebih dalam karena belum ditemukan adanya keterkaitan dengan ilusi dikotomi alam versus budaya dan maskulinitas laki-laki. Oleh sebab itu, melalui penelitian terhadap film genre biographical survival drama, argumen utama dalam penelitian ini yakni bahwa dikotomi alam versus manusia yang dihadirkan dalam film Jungle (2017) memberikan pandangan baru terkait hubungan manusia dan alam terutama melalui kerangka maskulinitas laki-laki. 
Hubungan antara manusia dan alam menjadi hal yang membentuk dikotomi pada keduanya. Selain itu, alam juga dimaknai sebagai yang inferior dari manusia, terutama laki-laki. Dikotomi yang paradoksal tersebut muncul dalam berbagai media, seperti dalam film Jungle (2019). Keempat tokoh laki-laki dalam film yang memiliki ketertarikan terhadap alam liar dan dorongan untuk menaklukkan alam; memandang alam sebagai ajang membangun kedirian seorang pria. Berdasarkan hal tersebut, masalah utama yang akan diangkat dalam penelitian ini adalah bagaimana pola perilaku laki-laki terhadap alam pada film Jungle (2017) mengonstruksi identitas maskulinitas laki-laki. Dengan demikian, penelitian ini bertujuan untuk meneliti bagaimana konstruksi hubungan alam dan manusia melalui kerangka maskulinitas menghadirkan maskulinitas ekologis sebagai bentuk negosiasi maskulinitas hegemonik dalam film Jungle (2017) dengan menggunakan teori maskulinitas ekologis dari Hultman dan Pulé.

\section{B. Metode}

Penelitian ini menggunakan metode kualitatif dengan pendekatan ekokritisisme. Sumber data yang digunakan yaitu adegan-adegan dalam film berjudul Jungle (2017), terutama terkait representasi hubungan alam dan manusia. Penelitian ini membahas bagaimana dikotomi alam versus manusia yang dihadirkan dalam film Jungle (2017) memberikan pandangan baru terkait hubungan manusia dan alam terutama melalui kerangka maskulinitas laki-laki. Untuk memecahkan permasalahan tersebut, penelitian ini menerapkan ekokritik sastra. Kerangka teori yang digunakan yakni teori maskulinitas ekologis. Maskulinitas dipahami sebagai suatu kemandirian, kekuatan, dan orientasi tindakan (Carlyle, 1992, p. 181). Konstruksi nilai-nilai maskulinitas dikaji melalui representasi hubungan laki-laki dan alam, yakni pola perilaku dan pandangan laki-laki terhadap alam liar. Untuk membedah persoalan tersebut, penelitian ini mengaplikasikan kerangka teori maskulinitas ekologis oleh Martin Hultman dan Paul M. Pulé dalam Ecological Masculinities: Theoretical Foundations and Practical Guidance (2018) terkait konsep ekologi maskulin yang mencakup dua hal. Pertama, nilai-nilai maskulinitas laki-laki modern Barat melalui karakteristik dari Paul Kivel.

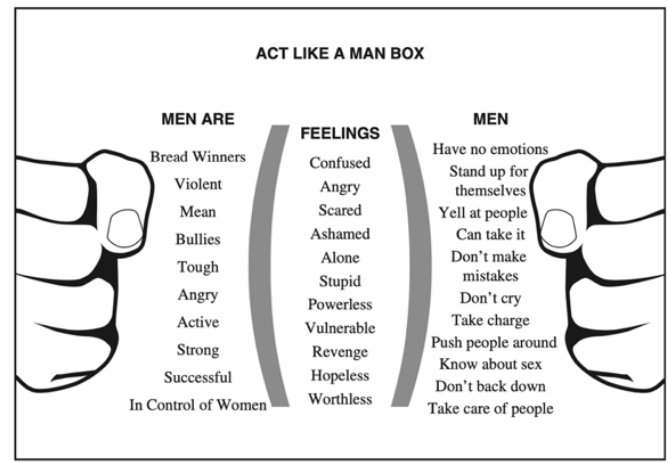

Gambar 1. Karakteristik maskulinitas Paul Kivel

(Hultman \& Pulé, 2018, pp. 37-40) 
Melalui karakteristik Paul Kivel tersebut, konstruksi maskulinitas laki-laki secara dinamis berubah dengan adanya faktor emosional manusia, seperti kegembiraan, rasa sakit, frustrasi, penghinaan, kesedihan, kesepian, harga diri, dst. Konsep maskulinitas ini digunakan untuk melihat konstruksi-konstruksi maskulinitas yang dihadirkan dalam film Jungle melalui keempat tokoh laki-laki. Kedua, ecological masculinities, konsep ini terkait dengan dampak dari konstruksi nilai-nilai maskulinitas terhadap kehidupan laki-laki, khususnya elemen ekologisasi. Maskulinitas ekologis hadir sebagai ekspresi yang lebih luas dari sekedar kepedulian terhadap alam, brotherhood, dan laki-laki sebagai individual, yakni dengan cara menentang hegemoni maskulinitas (Connell, 1990, pp. 452-478). Konsep maskulinitas ekologis ini akan digunakan untuk menguraikan bagaimana dikotomi alam versus laki-laki dalam kerangka maskulinitas dihadirkan dalam film Jungle (2017).

Dalam penelitian ini, data dikumpulkan dari seluruh scene dalam film yang berdurasi 115 menit. Data yang dikumpulkan merupakan adegan-adegan terkait persoalan maskulinitas yang direpresentasikan melalui hubungan alam dan manusia. Selanjutnya, analisis dilakukan pada aspek naratif seperti cerita, dialog, dan elemen formal dalam film. Kerangka teori maskulinitas hegemonik dan maskulinitas ekologis digunakan dalam penelitian ini untuk menganalisis isu utama tentang maskulinitas ekologis. Kemudian, isu tersebut juga dielaborasi menggunakan non-naratif aspek melalui elemen Mise-en-scene dalam film atau sinematografi menggunakan konsep Boggs dan Petrie (2017) seperti bagaimana signifikansi shot, point of view, dan elemen sinematografis lainnya dalam film.

\section{Pembahasan}

\section{Jungle (2017): Alam Menakutkan dan Berbahaya}

Adegan pembuka dalam film menunjukkan Yossi Ghinsberg, tokoh utama, sebagai seorang petualang dari Israel yang telah mengabdi sebagai tentara selama 3 tahun. Menaiki sebuah truk pengangkut makanan dan hewan ternak, Yossi dengan bahagia melihat tebing-tebing pegunungan Cordillera. Kemudian, dalam perjalanan menyeberang dengan perahu, Yossi bertemu dengan Marcus Stamm, guru sekolah dari Swiss dan temannya, Kevin Gale, seorang fotografer Amerika. Yossi telah mengenal Kevin atas kehebatannya mendaki banyak gunung dan mengambil foto dengan sangat baik. Selain itu, Yossi juga bertemu dengan seorang wanita, yang tidak disebutkan namanya dalam film, namun memiliki kedekatan dan dalam imajinasi Yossi ketika minum bersama, hutan, api, kupu-kupu digambarkan memiliki hubungan emosional dengan Yossi. Meninggalkan tempat berkemah, Yossi, Marcus, dan Kevin tinggal di La Paz, dan kemudian Yossi bertemu dengan orang asing warga negara Austria, Karl Ruprechter, yang mengajaknya untuk masuk ke hutan belantara dan mencari suku Indian. Hal tersebut sesuai dengan keinginan Yossi dalam narasi sebagai adegan pembuka film. 
Yossi : I left Israel in 1980, after three years in the army. I was desperate to escape to the well-worn path. You know, high school, university, work, marriage, kids. Not me. I wanted to be different, to experience the extraordinary, and to enter the unknown, discover lost tribes, the hidden treasures, the darkest heart of the jungle. (00:00:28)

Kutipan tersebut mengidentifikasi keinginan dari Yossi terhadap alam liar yang begitu besar, dan menunjukkan bahwa mengeksplorasi alam dan berada jauh dari hiruk pikuk perkotaan dan kegiatan sosial manusia merupakan bagian dari jati dirinya. Alam, eksplorasi tempat, dan petualangan menjadi suatu hal yang diperbincangkan di antara Yossi, Marcus, dan Kevin dari awal pertemuan dan dianggap suatu kehebatan. Pertemuannya dengan Karl menjadi kesempatan besar untuk melakukan hal-hal yang sangat diinginkan Yossie di Bolivia. Berdasarkan berbagai kehebatan yang ditawarkan hutan dalam benak Yossi dan Kevin, akhirnya Yossi dan Kevin bersama Marcus mengikuti Karl untuk masuk ke dalam hutan Amazon.

Terdapat beberapa area dalam menganalisis hubungan alam dan manusia yang terbagi menjadi empat: wilderness, the scenic sublime, the countryside, dan the domestic picturesque (Barry, 2002, p. 254). Melalui film Jungle (2017) penelitian ini akan melihat bagaimana hubungan manusia dan alam pada area wilderness (hutan belantara). Alam liar, khususnya hutan Amazon diposisikan sebagai sesuatu yang buruk, liar, menakutkan, dan mampu membunuh manusia. Melalui hutan Amazon, alam digambarkan tidak bisa bersahabat dengan manusia. Awal film dengan jelas menggambarkan alam di bumi ini yang masih alami dan belum terjamah oleh manusia. Hutan belantara Amazon terlihat gelap dan megah, dan faktanya adalah bahwa Amazon merupakan hutan hujan terbesar di dunia. Amazonia adalah apa yang orang sebut 'sangat besar', kawasan hutan hujan tropis berbentuk piring dan sabana rumput yang banyak menutupi bagian utara di Amerika Selatan, tidak banyak cahaya, dan dikenal sebagai hutan hujan Amazon, lembah sungai Amazon, atau hanya Amazon (Berkenkamp, 2008, pp. 5-10).

Dalam film Jungle (2017), banyak penggambaran tempat-tempat indah di Amerika Selatan seperti pegunungan, sungai, dan hutan belantara, yang ditampilkan sebagai tempat-tempat ekstrem dan penuh kebebasan. Penggambaran alam dalam film ini terlihat alami dengan penduduk lokal seperti pada kehidupan nyata; National Indian Foundation (FUNAI), sebagai organisasi yang bertujuan untuk melindungi hak-hak pendidikan asli Amazon, menyatakan bahwa sebagian besar penduduk asli Amazon memiliki kontak dengan dunia luar, tetapi beberapa suku benar-benar terisolasi (Berkenkamp, 2008, p. 13). Penghadiran suku-suku dengan kearifan lokal juga sebagai pembanding dengan sistem modern yang lebih antroposentris. Sementara itu, kearifan lokal cenderung menggunakan sistem dengan kelestarian alam (Febriyanto, Nurjana, Anista, \& Mardiansya, 2021, p. 323). Suku-suku inilah yang sangat ingin ditemui oleh tokoh laki-laki dalam film Jungle. Alam digambarkan dapat menjadi jati diri manusia melalui tokoh Yossi yakni dengan bepergian atau melakukan perjalanan menuju alam sebagai salah satu hal yang dapat memenuhi jiwanya. Hal ini terlihat dalam dialog tokoh Yossi dengan teman-temannya 'We are going to have the best 
time' (00:13:02), yang menunjukkan bahwa pergi ke jantung hutan Amazon adalah hal yang terbaik dalam hidupnya. Akan tetapi, pada akhirnya film ini tidak menampilkan bahwa alam menjadi sahabat manusia. Dalam artian lain, meskipun dapat bertahan hidup di alam, karakter utama ditampilkan kurang terlatih untuk mampu bertahan hidup di tengah alam, oleh karena itu dia tidak mencapai tujuannya; dan tokoh Karl yang mengklaim mengerti segalanya tentang alam, terutama hutan justru tidak pernah kembali dari hutan.

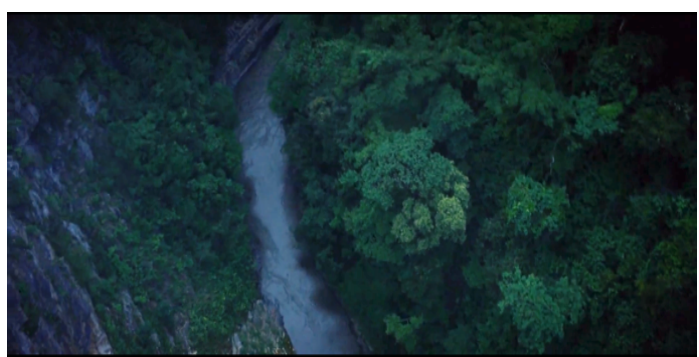

(a)

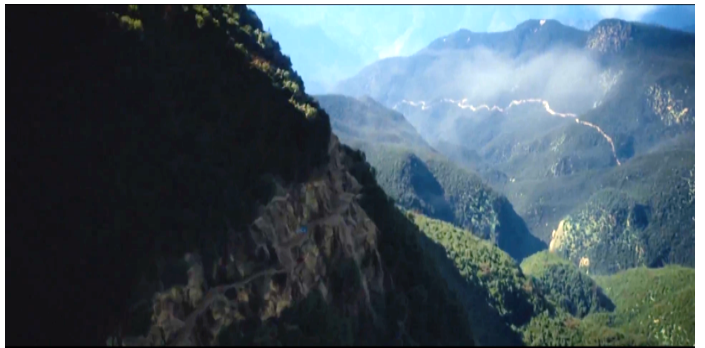

(b)

Gambar 2. Hutan Amazon (a) dan jalanan maut (death road) di Bolivia (b)

Pada Gambar 2a dan 2b, dapat dilihat penggambaran alam dalam film melalui hutan dan sungai Amazon, serta jalanan Bolivia. Pengambilan gambar alam secara extreme long shot dengan jarak yang sangat jauh biasa digunakan untuk menunjukkan keadaan atau lanskap di sekitar karakter. Bidikan kamera yang tinggi dengan gerakan kamera yang lambat digunakan dalam film ini ketika menggambarkan alam, seolah-olah kamera perlahan-lahan melayang di atas pemandangan, dan kesannya adalah penonton yang jauh dan terpisah dari alam (Boggs \& Petrie, 2017, p. 131). Selain itu, alam direpresentasikan dengan pencahayaan redup cenderung gelap dan warna emosional seperti pada Gambar 2 yang mendeskripsikan suasana alam yang menakutkan. Menggunakan sudut pandang director's interpretive yang menekankan bahwa alam dilihat dari sudut pandang yang berbeda, dalam hal ini alam liar yang menakutkan dan berbahaya. Representasi alam liar hutan Amazon dalam film digambarkan melalui visualisasi yang mirip dengan realitas hutan Amazon berdasarkan Berkenkamp (2008) dalam buku Discover The Amazon: The World's Largest Rainforest. Penonton akan memandang hal tersebut seolah-olah seperti yang mereka alami secara nyata jika berada di alam liar.

\section{Dikotomi Alam Versus Manusia}

Representasi hubungan alam yang menakutkan dan berbahaya dengan tokoh manusia terutama tokoh laki-laki bermakna adanya pemisahan antara alam dan manusia, hingga pemisahan tersebut membentuk dikotomi antara alam versus budaya (hasil tindakan manusia dan segala aspek kehidupannya). Penggambaran alam yang muncul pertama kali dalam film yakni North Yungas Bolivia, jalan yang indah namun mematikan sehingga dalam film diperkenalkan sebagai death road. Jalan inilah yang pertama kali menampilkan tokoh utama, 
Yossi, memulai perjalanannya di Bolivia. Kita dapat melihat bahwa alam, melalui jalan ini ditampilkan dari sisi yang terang dan gelap (Gambar 2b) pada sisi jalan yang dilalui Yossi dengan truk pengangkut. Yossi dan truk pengangkut hampir tidak terlihat dengan lanskap alam yang begitu luas. Hal tersebut tampak jelas menampilkan bahwa manusia hidup menjadi bagian dari alam. Film Jungle dengan jelas menghadirkan kritik ekologi berkaitan dengan hadirnya dikotomi hubungan alam dan manusia. Sebagaimana dikemukakan oleh Glotfelty \& Fromm (1996, p. xix) bahwa kritik ekologi memiliki konsep dasar bahwa dunia fisik (alam) adalah terhubung dengan budaya manusia.

Tokoh Yossi dan truk pengangkut digambarkan sangat kecil jika dibandingkan dengan lanskap alam yang diambil melalui extreme long shot sehingga menyiratkan bahwa manusia sangat kecil dan menjadi tidak penting secara visual; ia tampak tidak penting dan tidak berdaya (Giannetti, 2014, p. 10). Hal tersebut menunjukkan bahwa film menghadirkan dikotomi alam versus manusia di mana alam lebih mendominasi daripada manusia. Akan tetapi, di sisi lain justru penghadiran tokoh laki-laki (Yossi, Karl, Kevin, dan Marcus) memberikan makna bahwa manusia atau laki-laki lebih mendominasi alam. Hal ini terlihat dalam beberapa pola pikir dan perilaku tokoh laki-laki terhadap alam.

\footnotetext{
Karl : We don't like wild. We don't like untamed. We're obsessed with control. So, we ruin our planet.

Kevin : How did you know it was gonna rain?

Karl : I know everything. (00:15:39)
}

Pertama, dalam percakapan ketika mereka memulai perjalanan masuk ke hutan, Karl sebagai pemimpin mengungkapkan bahwa kita (manusia) adalah entitas yang terobsesi dengan kekuasaan. Kata kekuasaan merujuk pada bagaimana manusia menguasai alam sehingga menciptakan hal-hal yang berkedok pembangunan, peradaban, dan perlindungan terhadap alam, seperti halnya teknologi. Dialog Karl mengidentifikasi bahwa manusia atau laki-laki adalah kelompok yang tidak menyukai alam liar, dan menyukai kekuasaan. Finucane et al. (2000, pp. 161, dalam Hultman \& Pule, 2018) menguraikan bahwa kekuasaan yang digambarkan Karl merupakan persimpangan antara gender, kelas, dan ras; laki-laki kulit putih cenderung tidak terlalu menyukai alam liar hingga mengambil risiko untuk masuk ke dalam alam liar. Sebaliknya, mereka cenderung menciptakan, mengelola, dan menggunakan teknologi untuk mengeksploitasi dan menaklukkan alam.

Bagaimanapun, terdapat ilusi dikotomi alam versus manusia dari percakapan Karl tersebut. la menjelaskan bahwa seolah-olah dirinya tidak termasuk dalam kategori manusia yang terobsesi dengan kekuasaan. Di sisi lain, tokoh Karl mengklaim bahwa dia lebih mengetahui alam dan menguasai alam. Dalam suatu adegan dia mengatakan bahwa ia tidak akan kelaparan jika berada dalam hutan; ketika bertemu dengan seekor monyet dia menembak dan memakannya, kemudian mengatakan bahwa itu akan menjadi makanan terbaik. Dominasi manusia atas alam termasuk binatang menunjukkan hierarki bahwa manusia berada di atas alam termasuk tumbuhan dan binatang. Dalam film ini, keputusan Karl berbeda dengan keyakinan tokoh-tokoh lain, bahwa ia tidak berpikir jika 
alam liar dan hutan belantara merupakan hal yang berbahaya. Hal ini menjadikan Karl begitu berani dalam alam liar hingga menghadirkan ilusi antara dominasi Karl terhadap alam, atau alam yang lebih unggul dibandingkan dengan manusia.

Kedua, bagi tokoh Karl, alam liar merupakan hal yang harus ditaklukkan. Dialog Karl dengan Yossi mengenai konsep "man of action" menunjukkan bahwa laki-laki harus selalu identik dengan tindakan dan perbuatan daripada diskusi dan perenungan (menit 00:46:23). Dalam perspektif budaya Amerika, man of action berkaitan dengan konsep manhood (Holt \& Thompson, 2004, pp. 425-440). Hal tersebut menunjukkan bahwa alam menjadi sarana manusia, terutama laki-laki untuk menunjukkan identitas gender. Pergi ke alam berarti menaklukkan alam sehingga berujung pada pemaknaan bahwa laki-laki mendominasi alam. Akan tetapi, di sisi lain memandang alam sebagai sesuatu yang harus ditaklukkan dan menantang berarti bahwa alam memang berada dalam posisi yang lebih tinggi dari manusia sehingga laki-laki tertantang untuk menguasai alam.

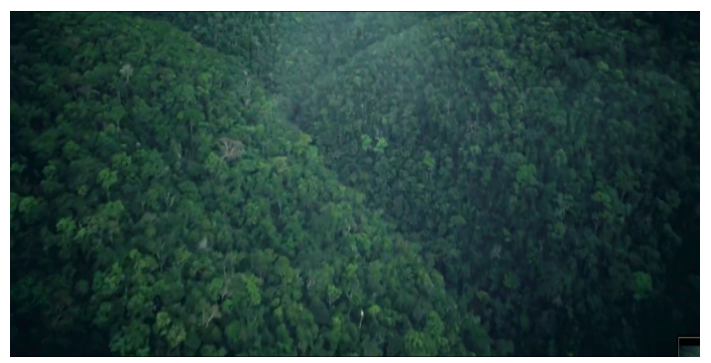

Gambar 3. Hutan Amazon

Selanjutnya, dikotomi alam versus manusia juga menghadirkan alam sebagai suatu entitas yang mendominasi manusia. Hal ini terlihat dalam adeganadegan bertahan hidup di hutan belantara Amazon, yakni bagaimana tokoh Marcus dan Yossi ditampilkan ketika kesakitan. Marcus mengalami luka-luka pada kakinya ketika melakukan perjalanan di hutan hingga teman-temannya merasa bahwa Marcus menjadi beban mereka, dan hal tersebut membuat Marcus menangis. Selanjutnya, Yossi juga mengalami kesakitan ketika parasit bersarang di dahinya. Pengambilan gambar pada adegan-adegan ini menggunakan extreme close-up, dengan menghadirkan luka-luka tersebut dalam satu frame penuh. Menurut Boggs \& Petrie (2017, pp. 19-20) pengambilan extreme close-up digunakan untuk menunjukkan secara detail ideologi dan kondisi emosional karakter; dalam hal ini kengerian dari apa yang dialami oleh Marcus dan Yossi ketika berada dalam hutan. Kemudian, ketika Yossi bertahan hidup di alam liar, dihadirkan pula halusinasi dengan kemunculan suara dan tokoh Marcus secara tiba-tiba yang semakin menjadi efek menyeramkan. Selain itu, masih dengan extreme close-up dihadirkan beberapa citraan binatang sebagai bagian ekosistem alam liar, seperti semut api, laba-laba, kalajengking, ular, dan adegan ini ditutup dengan penghadiran lanskap hutan Amazon seperti pada Gambar 4. Terdapat kombinasi ironis antara keindahan dan kengerian yang menciptakan efek yang kuat yakni efek horor yang bertujuan menghadirkan kekuatan untuk mengubah peristiwa yang menyebabkan ketidakstabilan dan 
yang harus ditantang dan dikalahkan (Martin, 2019, p. 4); dalam hal ini yaitu kekuatan alam terhadap manusia.

Kemudian, tidak kembalinya tokoh Karl dan Marcus dari alam liar pada akhir film menunjukkan bahwa hidup di alam liar tidak semudah yang Karl pikirkan . Di hutan Amazon, Karl melakukan banyak hal yang dia inginkan tanpa ada aturan seperti menggunakan senapan untuk membunuh binatang. Karl berpikir bahwa hidup di hutan belantara seperti Amazon adalah mudah dan menyenangkan daripada harus berurusan dengan masyarakat modern yang sangat kapitalistik. Hal tersebut terlihat dalam dialognya ketika mengajak Yossi: "There's nothing like the jungle at night. It's the most alive sound. Insects, birds. All these animals around you. It's like they're screaming at you... Pulsing like electricity" (00:09:40). Kata-kata Karl menunjukkan bahwa tidak ada yang perlu ditakutkan untuk hidup di dalam hutan alam liar. Karl tidak pernah membicarakan risiko ketika hidup di dalam hutan, yang ada hanyalah bahwa hutan akan menyediakan segalanya bagi manusia. Marcus yang selalu lebih percaya pada Karl dari awal hingga menyebutnya "Papa" juga tidak kembali dari hutan seperti halnya Karl di akhir film. Tragedi tidak kembalinya Karl dan Marcus meskipun telah dilakukan pencarian menunjukkan bahwa hidup di alam liar tidak semudah yang Karl pikirkan. Hal tersebut juga menunjukkan bahwa apa yang Karl percayai mengenai alam yaitu alam yang ramah terhadap manusia merupakan suatu ilusi atau romantisasi belaka. Pola pikir dan perilaku tokoh laki-laki terhadap alam tersebut menghadirkan ilusi dikotomi alam versus manusia, bahwa tokoh laki-laki mencoba menghadirkan pemahaman bahwa manusia lebih unggul dari alam. Oleh karena itu, film Jungle mencoba menghadirkan kritik terhadap antroposentrisme bahwa manusia bukan menjadi yang paling unggul dan manusia hanya bagian kecil dari alam.

\section{Maskulinitas Ekologis: Negosiasi Maskulinitas Hegemonik}

Representasi dikotomi hubungan alam versus manusia melalui tokoh laki-laki terhadap alam liar dalam film Jungle tersebut mengonstruksi cara pandang terhadap hubungan alam dan manusia. Pola pikir dan perilaku tokoh laki-laki terhadap alam membuktikan adanya kerangka maskulinitas yang membentuk konstruksi hubungan alam dan manusia. Beberapa kerangka maskulinitas hegemonik muncul dalam film. Dominasi laki-laki dalam konstruksi sosial telah terbentuk dalam masyarakat sehingga menimbulkan beberapa kategori yang jika tidak dipenuhi oleh laki-laki ia akan dianggap tidak maskulin, atau justru menjadi feminin. Paul Kivel (1998) menguraikan peran pria dan maskulinitas dari anak laki-laki yang mengadopsi seperangkat norma 'laki-laki' yang telah ditentukan sebelumnya. Kategori Kivel menunjukkan bahwa perasaan seperti cinta, kegembiraan, rasa sakit, frustrasi, penghinaan, kesedihan, kebencian, kesepian, harga diri, kasih sayang, dll. secara luas dianggap feminin dalam masyarakat yang didominasi oleh norma-norma laki-laki. Hultman \& Pulé (2018, p. 38) menambahkan jika pesan umum dan tradisional tentang ekspresi kedewasaan yang ingin disampaikan oleh Kivel adalah jelas: anak laki-laki dan laki-laki diharapkan mempertahankan posisi mereka, mengambil alih berbagai situasi, 
mengejar banyak wanita dan menjalin hubungan seksual dengan sebanyak mungkin dari mereka, menjadi misoginis dan homofobia, menghasilkan uang dan memikul tanggung jawab untuk teman, keluarga, dan negara, dan idealisasi mereka untuk laki-laki.

Beberapa hal tersebut dihadirkan secara implisit dalam film Jungle, meliputi, yang pertama, bagaimana satu-satunya tokoh perempuan yang dihadirkan dalam film yang memiliki kesempatan berbicara dengan Yossi hanya ditampilkan sebagai pasangan sementara Yossi ketika berada di perkemahan. Selain itu, perempuan tersebut hanya muncul dalam fantasi Yossi ketika bertahan hidup di tengah alam liar. Tokoh perempuan lain yang muncul yakni anggota komunitas pribumi yang ditampilkan tidak berbicara, dan Yossi menganggap perempuan tersebut membutuhkannya untuk bertahan hidup di alam, namun akhirnya tokoh tersebut justru meninggalkan Yossi. Tokoh-tokoh perempuan yang hanya mengambil ruang untuk hubungan seksual dan berada di bawah tanggung jawab laki-laki menunjukkan bahwa terdapat kerangka maskulinitas laki-laki hegemonik masyarakat Barat yang dihadirkan dalam film Jungle berdasarkan kategori maskulinitas Kivel (Hultman \& Pulé, 2018, p. 38). Kemunculan tokoh perempuan pertama dalam film dalam hubungan seksual dengan Yossi, dan ketika berfantasi mengenai kengerian alam liar mengidentifikasi bahwa perempuan dan alam liar setara dalam hal yang harus ditaklukkan oleh laki-laki. Dengan kata lain, alam liar dapat menjadi alternatif bagi laki-laki, yaitu sebagai instrumen untuk menunjukkan dominasi maskulinitas. Menurut Holt \& Thompson (2004, p. 427) laki-laki yang cenderung tidak tahan dengan konstruksi sosial dalam masyarakat akan tinggal di hutan belantara. Mereka cenderung memberlakukan maskulinitas 'mistis' yakni mengandalkan kelicikan, tekad, dan kekuatan individu mereka tidak hanya untuk bertahan hidup di alam tetapi juga menaklukkannya (Holt \& Thompson, 2004, p. 427).

Selanjutnya, kesenangan Yossi pada petualangan alam liar daripada kehidupan sosial (pendidikan dan pernikahan) menunjukkan bahwa laki-laki memiliki pilihan alternatif. Pada uraian analisis sub bab pertama telah dipaparkan bahwa tokoh Yossi tidak bisa beradaptasi dengan kehidupan sosial masyarakat seperti memiliki pendidikan, pekerjaan, dan terlibat dalam pernikahan. Maka, petualangannya di alam liar menjadi alternatif yang dimiliki sebagai laki-laki untuk memenuhi keinginan selain dari kehidupan sosial masyarakat. Pendidikan, pekerjaan, dan pernikahan dalam konsep maskulinitas Kivel termasuk dalam perasaan tanggung jawab laki-laki terhadap segala hal yang juga disebutkan oleh Hultman \& Pulé. Dengan kemudian, laki-laki lebih memilih hubungan dengan alam tersebut menjadi bagian dari negosiasi mereka. Masyarakat Barat juga menempa ideologi maskulinitas yang mendukung cita-cita maskulinitas bahwa laki-laki harus sepenuhnya bebas, berada di tengah alam, dan tidak terbelenggu otoritas institusional yang mengikat atau batasan penilaian sosial (Holt \& Thompson, 2004, pp. 427-428). Hal ini juga berlaku dalam pernikahan yang mungkin melibatkan perasaan cinta yang membatasi laki-laki, sedangkan untuk berhubungan seksual saja seperti pada film Jungle laki-laki tidak membutuhkan hal tersebut. 
Sementara itu, jika pola pikir dan perilaku Karl terhadap alam lebih menunjukkan adanya ilusi dikotomi alam versus manusia, maka pola pikir dan perilaku tokoh Marcus dapat menunjukkan tingkat maskulinitas laki-laki. Dari awal film, naratif film menunjukkan adanya pola berulang bagaimana tokoh Marcus dihadirkan sebagai tokoh yang selalu membutuhkan pertolongan orang lain dan lemah. Bagaimanapun, maskulinitas hegemonik menghadirkan laki-laki sebagai penolong dan memiliki kekuatan sehingga mampu memikul tanggung jawab. Dengan kata lain, film ini juga berusaha menampilkan kerangka maskulinitas dengan melakukan perbandingan secara implisit dengan kerangka feminin melalui tokoh Marcus. Dari perdebatan konstruksi maskulinitas dan feminitas tersebut dihadirkanlah maskulinitas ekologis sebagai negosiasi dan alternatif maskulinitas hegemonik. Terdapat tiga model maskulinitas menurut Hultman \& Pulé (2018, pp. 40-54) yakni Industrial/breadwinner masculinities, ecomodern masculinities, dan ecological masculinities.

Pertama, industrial/breadwinner masculinities merupakan maskulinitas lakilaki yang hadir dalam patriarki, hegemonik, dan normatif; dalam konteks ekologi, maskulinitas ini menghadirkan bahwa laki-laki secara historis dihargai karena mengejar praktik eksploitasi (Hultman \& Pulé, 2018, p. 40). Kata industri dalam model maskulinitas ini merupakan implikasi dari industrialisasi seperti perkataan tokoh Karl mengenai obsesi manusia pada kekuasaan dan teknologi hingga merusak alam. Hegemonisasi maskulin telah menerapkan ideologi kemapanan bagi laki-laki, dan dalam film (Jungle) hal ini muncul secara tidak langsung dalam percakapan Yossi dan tokoh perempuan mengenai ayah Yossi.

\footnotetext{
Yossi : : I think I should send this book to my father.

Perempuan : Doesn't he like you on the road?

Yossi : It's not that he doesn't like. He just can't understand it. And so he thinks I'm throwing my life away. (00:07:28)
}

Kutipan dialog Yossi dengan tokoh perempuan tersebut menunjukkan konstruksi peran laki-laki bahwa seharusnya laki-laki memiliki pekerjaan dan menikah, bukan dengan berada di 'jalanan' yang berarti bertualang seperti yang dilakukan Yossi. Kedua, maskulinitas ecomodern menawarkan keseimbangan antara persoalan sosial dan ekologi; maskulinitas ini membentuk pemahaman bahwa laki-laki bekerja meningkatkan perekonomian sekaligus peduli terhadap permasalahan lingkungan yang disebabkan industrialisasi (Hultman \& Pulé, 2018, p. 47). Model kedua ini secara implisit dihadirkan dalam film melalui tokoh Kevin, bahwa sebagai fotografer terkenal ia menggunakan alam sebagai bagian dari pekerjaannya. Keputusan Kevin untuk mengikuti Karl dan Yossi disebabkan oleh perkataan Karl bahwa Kevin dapat mengambil bagian di National Geographic setelah menemukan suku Toromonas. Hal ini mengidentifikasi bahwa Kevin tidak sepenuhnya peduli dengan alam, tetapi alam merupakan bagian dari pekerjaannya.

Sementara itu, model ketiga maskulinitas yakni ecological masculinities sebagai pilihan atau alternatif lain dari maskulinitas hegemonik dan ekomodern, yang dimaknai sebagai negosiasi maskulinitas hegemonik dan ekomodern (Hultman \& Pulé, 2018, p. 51). Bagaimanapun, ecological masculinities 
menghadirkan alam secara penuh sebagai negosiasi bagi laki-laki; sehingga lakilaki memiliki ekspresi yang bebas (Connell, 1990). Hultman \& Pulé (2018, pp. 5354) memosisikan maskulinitas ekologis sebagai titik temu antara laki-laki, maskulinitas, dan bumi (alam) bahwa lanskap sosial-politik Barat yang terindustrialisasi sangat membutuhkan transformasi dari hegemonisasi ke ekologisasi. Melalui film Jungle (2017), tokoh utama laki-laki, Yossi dihadirkan sebagai simbol yang menjadikan alam untuk jalan kebebasan dan mengekspresikan keinginannya. Tokoh Yossi merupakan model ADAM- $n$ (Adam jenis baru) yakni dalam konsep maskulinitas ekologis sebagai laki-laki yang mendukung transformasi maskulinitas hegemonik menuju ekologisasi (Hultman \& Pulé, 2018, p. 231). Transformasi dan negosiasi Yossi sepenuhnya melalui alam dan hutan belantara, alih-alih berfokus dengan persoalan sosial dan berhubungan dengan konstruksi sosial terhadap apa yang harus dia lakukan sebagai laki-laki, Yossi justru bertualang mengekspresikan keinginan dan kebebasannya.

Selanjutnya, model $A D A M-n$ merupakan akronim dari lima sila dalam proses ekologisasi maskulin yakni $A$ : awareness (kesadaran), berkaitan dengan kesadaran dalam mengelola keinginan dan perasaan diri sendiri; $D$ : deconstruction, sikap kritis dan sadar terhadap sistem konstruksi; $A$ : amendment, penggunaan sumber daya atau teknologi yang justru menghilangkan sikap dominasi; $M$ : modification, rekonstruktif kesetaraan dengan perempuan dan ras lain (mengakhiri segala bentuk dominasi); dan - $n$ : nourish new masculinities, dalam hal ini terdapat empat elemen yang dimiliki yakni zeal, superpower, hurts, dan wish (Hultman \& Pulé, 2018, pp. 231-243). Tokoh Yossi telah menghadirkan beberapa proses untuk memasuki maskulinitas ekologis seperti kesadaran akan keinginan dan mengelola keinginannya untuk melakukan petualangan, serta kesadaran akan sistem konstruksi di masyarakat. Selain itu, tokoh Yossi juga merangkul elemen-elemen yang menunjukkan pemeliharaan dalam maskulinitas ekologis seperti zeal (semangat) untuk menghabiskan sebagian besar waktu melakukan keinginan sendiri yakni bertualang; superpower (kekuatan) menurut Hultman dan Pulé (2018, pp. 239-240) keterampilan dalam hidup yang secara alami telah mahir, tokoh Yossi mahir dalam menjalin hubungan baik dalam bersosialisasi seperti membantu Marcus ketika pertama kali bertemu dan sebagai penengah ketika pertengkaran antara Marcus, Kevin, dan Karl. Kemudian, tokoh Yossi juga merangkul sifat wish (keinginan) untuk eksplorasi yang membawanya ke tempat-tempat terbaik seperti Alaska, New York, dan Vegas (menit 00:04:28).

Oleh karena itu, maskulinitas ekologis melalui alam liar dan hutan belantara tetap menghadirkan fungsi alam sebagai sarana laki-laki dalam mencapai tujuannya bernegosiasi dengan maskulinitas hegemonik. Menariknya, adegan terakhir film menunjukkan bahwa laki-laki dalam menggunakan alam sebagai instrumen negosiasi maskulinitas masih dipengaruhi oleh maskulinitas hegemonik. Hal ini terlihat, sebagai puncak dari perjuangan Yossi untuk bertahan hidup, ketika film menghadirkan kilas balik perjalanan Yossi sebelum memutuskan untuk masuk ke hutan belantara Amazon. Kilas balik dengan tokohtokoh dalam kehidupan sosial seperti tokoh Ibu, perempuan, Kakek, Marcus, dan 
Kevin justru memberi Yossi kekuatan untuk berlari keluar dari hutan belantara. Kilas balik ini menampilkan hubungan tokoh utama Yossi dengan keluarga dan hubungan sosial lainnya, yang menunjukkan bahwa maskulinitas hegemonik masih mendominasi. Saat masa lalu bersaing dengan masa kini, jepretan memori menghasilkan urutan kilas balik dan potongan fantasi yang akhirnya menjadi dominan, dan masa kini ditangguhkan sejenak (Giannetti, 2014, p. 153). Dengan kata lain, terdapat pergolakan dalam diri Yossi antara masa lalu (hubungan sosial dengan manusia) dan masa kini (hubungan dengan hutan belantara).

\section{Penutup}

Dikotomi alam versus manusia yang dihadirkan dalam film Jungle (2017) memberikan pandangan baru terkait hubungan manusia dan alam terutama melalui kerangka maskulinitas laki-laki. Bagaimanapun, manusia tetap menjadikan alam sebagai sarana dalam memenuhi kebutuhan. Melalui film Jungle (2017) alam direpresentasikan berbahaya dan mendominasi terhadap manusia. Akan tetapi, pola pikir dan perilaku tokoh laki-laki (Yossi, Marcus, Kevin, dan Karl) menghadirkan ilusi dikotomi alam versus manusia. Tokoh Marcus, Kevin, dan Karl merepresentasikan pola pikir dan perilaku maskulinitas hegemonik di mana sebagai lak-laki alam digunakan sebagai suatu tantangan, bagian dari pekerjaan, dan menunjukkan kekuatan laki-laki. Sementara itu, tokoh Yossi menganggap bahwa alam merupakan jalan kebebasan untuk dirinya, dan berekspresi dengan bebas tanpa konstruksi sosial masyarakat seperti pekerjaan, pendidikan, dan pernikahan. Maskulinitas ekologis hadir sebagai negosiasi maskulinitas hegemonik masyarakat patriarki yang menempatkan laki-laki sebagai yang mendominasi dalam berbagai aspek kehidupan. Berdasarkan konsepsi tersebut, maskulinitas ekologis menghadirkan laki-laki, maskulinitas, dan alam tidak berpusat pada konstruksi laki-laki sebagai yang mendominasi dan menindas, tetapi bagaimana mewujudkan de/rekonstruksi maskulinitas dan kehidupan laki-laki. Film ini menginspirasi cara pandang kita terhadap hubungan alam dan manusia, bahwa dengan merangkul alam dalam berbagai aspek kehidupan dapat menciptakan alternatif dari konstruksi sosial masyarakat, terutama konstruksi yang bersifat mendominasi dan menindas.

\section{Daftar Pustaka}

Barry, P. (2002). Beginning Theory: An Introduction to Literary and Cultural Theory. Second Ed. New York: Manchester University Press.

Batat, W., \& Wohlfeil, M. (2009). Getting Lost "Into the Wild": Understanding Consumers' Movie Enjoyment Through a Narrative Transportation Approach. Advances in Consumer Research, 36, 372-377. https://www.acrwebsite.org/volumes/14301/volumes/v36/NA-36

Berkenkamp, L. (2008). Discover the Amazon: World's Largest Rainforest. Vermont: Nomad Press.

Boggs, J. M., \& Petrie, D. W. (2017). The Art of Watching Films: Ninth Edition. New York: Mc Graw Hill. 
Boyle, D. (Director). (2010). 127 Hours [Motion Picture].

Buckmaster, L. (2017, Agustus 3). Jungle review - Daniel Radcliffe flounders through shallow Amazon misadventure. Retrieved from The Guardian: https://www.theguardian.com/film/2017/aug/04/jungle-review-danielradcliffe-flounders-through-shallow-amazon-misadventure

Carlyle, T. (1992). Race, Ethnicity and Difference: Competing Masculinities. In C. Hall, White, Male, and Middle Class: Explorations in Feminism and History (pp. 181-208). Massachusetts: Polity Press.

Connell, R. W. (1990). A Whole New World: Remaking Masculinity in the Context of the Environmental Movement. Gender \& Society, 4(4), 452-478. https://doi.org/10.1177/089124390004004003

Contessa, D. (2012). 127 Hours: A Cinematic Narrative of Ecological Identity. $\begin{array}{llll}\text { Humanity } \quad \text { S Society, } & 36(1),\end{array}$ https://doi.org/10.1177/0160597611433268

Croteau, M. (2020). Nature Versus Nurture/Wilderness Versus Words: yncretising Binaries and the Getting of Wisdom in Sean Penn's Into the Wild (2007). In D. Cartmell, \& A. D. Polase, A Companion to the Biopic, First Edition (pp. 209-229). New Jersey: John Wiley \& Sons, Inc.

Febriyanto, D., Nurjana, K., Anista, E., \& Mardiansya, D. (2021). Kearifan Lokal dalam Hikayat Komering Pitu Phuyang. Diglosia: Jurnal Kajian Bahasa, Sastra, dan Pengajarannya, 4(3), 321-334. https://doi.org/10.30872/diglosia.v4i3.227

Finucane, M. S. (2000). Gender, race, and perceived risk: the "white male" effect. Health, Risk \& Society, 2(2), 159-172. https://doi.org/10.1080/713670162

Giannetti, L. (2014). Understanding Movies. 13th Edition. New York: Pearson Education, Inc.

Glotfelty, C. a. (1996). The Ecocriticism Reader: Landmarks in Literary Ecology. Athens: University of Georgia Press.

Greven, D. (2009). Contemporary Hollywood Masculinity and the DoubleProtagonist Film. Cinema Journal, 48(4), 22-43. https://doi.org/10.1353/cj.0.0137

Holt, D. B., \& Thompson, C. J. (2004). Man-of-Action Heroes: The Pursuit of Heroic Masculinity in Everyday Consumption. Journal of Consumer Research, 31(2), 425-440. https://www.jstor.org/stable/10.1086/422120

Hultman, M., \& Pulé, P. M. (2018). Ecological Masculinities: Theoretical Foundations and Practical Guidance. London and New York: Routledge.

Iñárritu, A. G. (Director). (2015). The Revenant [Motion Picture].

Kivel, P. (1998). Men's Work: How to Stop the Violence That Tears Our Lives Apart. Minnesota: Hazelden Publishing.

Korteweg, L., \& Oakley, J. (2014). Eco-heroes out of place and relations: decolonizing the narratives of Into the Wild and Grizzly Man through Land education. Environmental Education Research, 20, 131-143. https://doi.org/10.1080/13504622.2013.865117

Loftsdóttir, K., Kjartansdóttir, K., \& Lund, K. A. (2017). Trapped in clichés: masculinity, films and tourism in Iceland. Routledge: Gender, Place, and Culture, 1225-1242. 
Martin, G. N. (2019). (Why) Do You Like Scary Movies? A Review of the Empirical Research on Psychological Responses to Horror Films. Frontiers in Psychology, 10, 1-22. https://doi.org/10.3389/fpsyg.2019.02298

McLean, G. (Director). (2017). Jungle [Motion Picture].

McLevy, A. (2017, November 16). Jungle pits Daniel Radcliffe against nature, with one of the grossest scenes of the year. Retrieved from AV Club: Movie Review: https://www.avclub.com/jungle-pits-daniel-radcliffe-against-naturewith-one-o-1819477754

Pan, Y. (2020). Human-Nature Relationships in East Asian Animated Films. Societies, 10(2), 1-13. https://doi.org/10.3390/soc10020035

Penn, S. (Director). (2007). Into the Wild [Motion Picture].

Potter, M.-A. (2019). Human-Nature-Technology interfaces within the Avatar cinema-scape. Image \& Text, 33, 1-16. http://dx.doi.org/10.17159/2617$3255 / 2018 / n 33 a 9$

Tierney, D. (2021). Interrogating (neo)colonialism in the contemporary western: Alejandro González Iñárritu's The Revenant (2015). Studies in Spanish \& Latin American Cinemas, 89-104. https://doi.org/10.1386/slac_00038_1

Zonn, L. E., \& Altken, S. C. (1994). Of Pelicans and Men: Symbolic Landscapes, Gender, and Australia's Storm Boy. In L. E. Zonn, \& S. C. Altken, Place, Power, Situation, and Spectacle: A Geography of Film (pp. 137-159). London: Rowman \& Littelfield Publishers. 
N. Rinahayu \& B. Kristianto 